\title{
VARIASI PEMBELAJARAN BAHASA INDONESIA MAHASISWA UNIVERSITAS BINA DARMA DI MASA PANDEMI
}

\author{
Ayu Puspita Indah Sari ${ }^{1}$, Hastari Mayrita ${ }^{2}$, \\ Dosen Universitas Bina Darma \\ Jalan Jenderal Ahmad Yani No. 3 Palembang \\ Sur-el: ayupuspita.indahsari@binadarma.ac.id"1, \\ hastari_mayrita@binadarma.ac.id ${ }^{2}$
}

Article info

Article history:

Received:12-10-2020

Revised : 18-12-2020

Accepted:28-12-2020

Keywords:

Variation, Indonesian

Language Learning,

Pandemic

Kata Kunci:

Variasi,

Pembelajaran Bahasa

Indonesia, Pandemi

\begin{abstract}
A B S T R A C T
This study aims to describe the variations in teaching lecturers, variations in assignments and inhibiting factors for learning Indonesian for Bina Darma University students during the pandemic using qualitative descriptive methods as well as through interviews and observations. Data analysis was carried out through data reduction, data presentation, and drawing conclusions. The results showed: (1) The teaching variations of the lecturers were very diverse, which was adjusted to the mastery and skills of the lecturers in using IT to interact with students, such as using E-Learning, E-Mail, Zoom, Google Classroom, WhatsApp, Youtube content; (2) Variations in assignment are also very diverse according to the ability of lecturers to use IT; (3) External and internal factors are inhibiting factors for the variation of Indonesian Language learning among Bina Darma University Students during the Pandemic Period.
\end{abstract}

Penelitian ini bertujuan mendeskripsikan variasi mengajar dosen, variasi pemberian tugas serta faktor penghambat pembelajaran Bahasa Indonesia mahasiswa Universitas Bina Darma di masa pandemi menggunakan metode deskriptif kualitatif serta melalui wawancara dan observasi. Analisis data dilakukan melalui reduksi data, sajian data, dan penarikan simpulan. Hasil penelitian menunjukkan:(1) Variasi mengajar dosen sangat beragam yang disesuaikan dengan penguasaan dan keterampilan para dosen dalam menggunakan IT untuk berinteraksi dengan mahasiswa seperti penggunaan konten E-Learning, E-Mail, Zoom, Google Classroom, WhatsApp, Youtube; (2) Variasi dalam pemberian tugas juga sangat beragam disesuaikan dengan kemampuan dosen dalam menggunakan IT; (3) Faktor eksternal dan internal adalah faktor penghambat variasi pembelajaran Bahasa Indonesia Mahasiswa Universitas Bina Darma di Masa Pandemi.

Direktorat Riset dan Pengabdian Masyarakat Universitas Bina Darma. 


\section{JURNAL ILMIAH \\ BINA EDUKASI \\ ISSN 1979-8598 E-ISSN: 2655-8378 \\ http://journal.binadarma.ac.id/index.php/jurnalbinaedukasi \\ Vol. 13, No. 2, Desember 2020, 66 - 75}

\section{PENDAHULUAN}

Seperti yang kita ketahui bahwa sebagian besar negara di dunia terkena dampak pandemi, khususnya di Indonesia. Aktivitas menjadi serba terbatas, berharap semoga pandemi segera berakhir dan aktivitas kembali normal.

Akhir-akhir ini pemerintah menetapkan New Normal, namun aktivitas peserta didik tidak sepenuhnya bebas. Pandemi ini sangat memberikan dampak yang luar biasa khususnya pada kita semua yang berada di lingkungan pendidikan. Adapun dampak-dampak tersebut seperti penutupan sekolah-sekolah dan kampus-kampus secara besar dan global sehingga mengakibatkan pendidikan berubah dramatis dengan ditandai adanya kebangkitan pembelajaran daring dimana para pengajar dan pendidik merasakan bahwa mereka mengalami migrasi digital, yang menuntut pelaku pendidikan secara global harus mempunyai strategi pembelajaran di masa pandemi ini atau yang sering kita sebut dengan pembelajaran jarak jauh (PJJ). Ini adalah masa penyesuaian dan pastinya sedikit sulit dilakukan dan akhirnya akan menimbulkan "stress". Pada masa-masa seperti ini kita merasa sangat bingung, merasa ketidakjelasan, dan ini wajar-wajar saja terjadi. Oleh sebab itu, jangan takut dan teruslah berusaha untuk meyakini bahwa usaha terbaik untuk mengetahui mengenai hal baru adalah bagaimana agar kita dapat keluar dari tempat nyaman dan itu adalah satu-satunya usaha guna memperbaiki diri. Sehingga, jika ada orang tua atau pengajar yang masih belum bisa menggunakan teknologi tidak mengapa, karena itu wajar saja. Akan tetapi kita harus mencoba untuk mempelajari metode yang terbaik. Kita menyadari bahwa sangat sulit menghadapi masa-masa seperti ini, oleh karena itu apa salahnya kita berusaha untuk mencoba menggunakan suatu metode baru dalam pembelajaran yang lebih efektif disesuaikan dengan kondisi seperti ini.

Pengajar atau pendidik mempunyai tugas dalam mewujudkan tujuan pembelajaran di kelas. Akan tetapi dalam situasi pandemi seperti ini, maka pengajar dan pendidik harus lebih kreatif melakukan pengembangan suatu rencana pembelajaran seefektif dan sevariatif mungkin. Pengembangan rencana pembelajaran tersebut bertujuan tidak lain agar dapat tercipta suatu keadaan pembelajaran yang dapat memberikan efek kepada peserta didik dan berharap mereka dapat merasa senang terlebih lagi mendapatkan prestasi yang memuaskan atas pembelajaran tersebut.

Berhasil atau tidaknya suatu kegiatan pembelajaran, tentunya faktor-faktor yang ada di sekeliling sangat memengaruhinya, baik yang berasal dari dalam maupun yang berasal dari luar, serta faktor-faktor lain yang mendukung baik yang berasal dari fisik maupun dari psikologis seperti faktor intelegensi, adanya perhatian, adanya minat atau kemauan, timbulnya bakat, motif, pematangan, sampai kepada adanya kesiapan. Faktor-faktor tersebut tentunya sebisa mungkin kita kerahkan utamanya di masa-masa pandemi seperti yang sekarang ini kita alami agar dapat 


\section{JURNAL ILMIAH \\ BINA EDUKASI \\ ISSN 1979-8598 E-ISSN: 2655-8378 \\ http://journal.binadarma.ac.id/index.php/jurnalbinaedukasi \\ Vol. 13, No. 2, Desember 2020, 66 - 75}

menjadi penunjang yang mampu membawa kegiatan pembelajaran menjadi lebih efektif. Pelaksanaan kegiatan belajar-mengajar secara efektif adalah suatu pekerjaan yang sangat beragam, hal ini dikarenakan bahwa pengajar dan pendidik dituntut sungguh-sungguh terampil dalam menerapkan berbagai hal yang dibutuhkan selama kegiatan pembelajaran berlangsung. Dengan adanya peningkatan proses pembelajaran tersebut, maka diharapkan hasil pembelajaran dapat dicapai secara optimal.

Penggunaan variasi dalam proses pembelajaran merupakan suatu alternatif dalam upaya menggairahkan proses pembelajaran di kelas yang sekarang lebih banyak dialihkan ke metode daring (dalam jaringan) mengingat siswa sering bosan dalam proses pembelajaran di kelas. Berdasarkan uraian-uraian tersebut, maka penulis mengangkat permasalahan yaitu "Bagaimana penggunaan variasi pembelajaran Bahasa Indonesia mahasiswa Universitas Bina Darma di masa pandemi?" serta "Faktor apa saja sebagai penghambat pada pelaksanaan variasi pembelajaran tersebut?. Sedangkan tujuan dari tulisan ini yaitu untuk mendeskripsikan variasi pembelajaran dan faktor penghambat variasi pembelajaran Bahasa Indonesia mahasiswa Universitas Bina Darma di masa pandemi.

Penelitian serupa sebelumnya pernah dilakukan oleh Paraningsih, dkk (2016) dalam Jurnal dengan judul "Variasi Mengajar Guru Bahasa Indonesia di Kelas VIII SMPN 2 Sawan". Hasil yang diperoleh dari penelitiannya tersebut menunjukkan "bahwa ada beberapa hal yang menonjol terkait dengan masalah yang diangkat, yakni (1) variasi mengajar guru yang meliputi gaya mengajar, hal yang paling menonjol adalah perubahan posisi. Variasi penggunaaan media dan bahan ajar yang paling menonjol adalah variasi media pandang. Variasi pola interaksi yang paling menonjol adalah pola interaksi satu arah. (2) Hambatan yang paling menonjol dalam mengadakan variasi mengajar adalah pola interaksi. (3) Usaha yang paling dilakukan guru dalam mengatasi masalah adalah mengadakan diskusi kelompok". Selanjutnya, Barokah, dkk (2020) dalam jurnal yang berjudul "Variasi Tugas dan Aktivitas Pembelajaran dalam Masa Pandemi Korona di SMK". Hasil penelitian menunjukkan "bahwa (1) Variasi tugas pembelajaran Bahasa Indonesia di SMKN 9 Surakarta dalam masa pandemi korona bervariatif. Variasi tugas tersebut antara lain mencari sebuah puisi yang berkaitan dengan pademi korona di internet, pembacaan sebuah puisi, mencari drama di internet maupun menonton drama di YouTube, dan memerankan tokoh drama sesuai dengan karakternya; (2) Aktivitas pembelajaran Bahasa Indonesia di SMKN 9 Surakarta dalam masa pandemi korona sangat beragam. Aktivitas yang dilakukan siswa dengan guru yaitu dengan memanfaatkan media internet, YouTube, WhatsApp dan google classroom". 


\section{METODOLOGI PENELITIAN}

\subsection{Variasi Pembelajaran}

\subsubsection{Pengertian Variasi dalam Pembelajaran}

Mulyasa (2013), mengatakan bahwa "variasi merupakan keterampilan yang harus dikuasai guru dalam pembelajaran, untuk mengatasi kebosanan peserta didik, agar selalu antusias, tekun dan penuh partisipasi”. Pandai menggunakan variasi adalah salah satu keterampilan dasar dalam mengajar. Alma (2009), mengatakan bahwa "membuat variasi adalah suatu hal yang sangat penting dalam prilaku keterampilan mengajar, yang dimaksud dengan variasi dalam hal ini adalah menggunakan berbagai metode, gaya mengajar misalnya variasi dalam menggunakan sumber bahan pelajaran media pengajaran, variasi dalam bentuk interaksi antara guru dan murid".

Berdasarkan pendapat ahli di atas maka dapat disimpulkan bahwa variasi dalam pembelajaran dimaksudkan yaitu upaya yang dilakukan oleh pengajar agar terciptanya suatu ragam penggunaan teknik atau metode yang mencakup dua konsep dalam proses atau kegiatan yang saling berkaitan dalam rangkaian peristiwa yang kompleks dan sistematis. Adapun dua konsep yang dimaksud tersebut yaitu belajar dan mengajar.

\subsubsection{Variasi-variasi dalam Proses Pembelajaran}

Majid (2013), mengatakan bahwa "variasi dalam kegiatan pembelajaran dapat dikelompokkan menjadi tiga bagian, yakni variasi gaya mengajar, variasi dalam penggunaan media dan bahan pelajaran, dan variasi dalam pola interaksi dan kegiatan". Lebih lanjut Mulyasa (2013), mengatakan bahwa "variasi dalam proses pembelajaran dapat dikelompokkan menjadi empat bagian, yakni variasi dalam gaya mengajar, variasi dalam penggunaan media dan sumber belajar, variasi dalam pola interaksi, dan variasi dalam pembelajaran.

\subsection{Variasi Pembelajaran di Masa Pandemi}

Berikut adalah beberapa variasi dalam pembelajaran di masa pandemi yang dikutip dari beberapa sumber:

1. Kemendikbud RI (2020), mengatakan bahwa ada tujuh tips mengajar di masa pandemi Covid-19: (1) jangan stress; (2) mencoba untuk membagi kelompok belajar menjadi kelompok kecil-kecil; (3) mencoba untuk project based learning; (4) alokasikan waktu yang lebih banyak bagi yang tertinggal; (5) fokus terhadap waktu yang paling penting; (6) saling interaksi dengan sesama guru; dan (7) have fun.

2. Sevima.com (2020), mengatakan bahwa "ada enam metode pembelajaran paling efektif di masa pandemi menurut para pakar sebagai berikut.

a. Project Based Learning. Metode project based learning ini diprakarsai oleh hasil implikasi dari Surat Edaran Mendikbud no.4 tahun 2020. Project based learning ini 


\section{JURNAL ILMIAH}

BINA EDUKASI

ISSN 1979-8598 E-ISSN: 2655-8378

http://journal.binadarma.ac.id/index.php/jurnalbinaedukasi

Vol. 13, No. 2, Desember 2020, 66 - 75

memiliki tujuan utama untuk memberikan pelatihan kepada pelajar untuk lebih bisa berkolaborasi, gotong royong, dan empati dengan sesama;

b. Daring Method. Metode daring ini sangatlah cocok diterapkan bagi pelajar yang berada pada kawasan zona merah. Dengan menggunakan metode full daring seperti ini, sistem pembelajaran yang disampaikan akan tetap berlangsung dan seluruh pelajar tetap berada di rumah masing-masing dalam keadaan aman;

c. Luring Method. Luring yang dimaksud pada model pembelajaran yang dilakukan di luar jaringan. Dalam artian, pembelajaran yang satu ini dilakukan secara tatap muka dengan memperhatikan zonasi dan protokol kesehatan yang berlaku;

d. Home Visit Method. Seperti halnya metode yang lain, home visit merupakan salah satu opsi pada metode pembelajaran saat pandemi ini. Metode ini mirip seperti kegiatan belajar mengajar yang disampaikan saat home schooling. Jadi, pengajar mengadakan home visit di rumah pelajar dalam waktu tertentu;

\section{e. Integrated Curriculum}

"Metode pembelajaran yang satu ini tidak hanya melibatkan satu mata pelajaran saja, namun juga mengaitkan metode pembelajaran lainnya. Dengan menerapkan metode ini, selain pelajar yang melakukan kerjasama dalam mengerjakan projek, dosen lain juga diberi kesempatan untuk mengadakan team teaching dengan dosen pada mata kuliah lainnya"; dan

f. Blended Learning. Metode blended learning adalah metode yang menggunakan dua pendekatan sekaligus. Dalam artian, metode ini menggunakan sistem daring sekaligus tatap muka melalui video converence.

3. Harususilo (2020) dalam Barokah, dkk (2020) "mengungkapkan bahwa ada empat variasi tugas yang diberikan guru kepada siswanya dalam masa pandemi corona, antara lain; (1) proyek membuat produk, seperti masker yang terbuat dari bahan yang tidak terpakai dari limbah kain dan hand sanitizier dari cairan pembersih lantai; (2) memanfaatkan laboratorium maya Rumah Belajar, yaitu portal Rumah Belajar Kemendikbud untuk pembelajan daring; (3) membuat $v \log$ atau video yang dapat dilakukan oleh guru dan siswa; dan (4) melakukan pembelajaran daring dan belajar aktif, dengan cara memanfaatan media internet untuk pembelajaran daring yang efektif".

\subsection{Metode}

"Deskriptif Kualitatif" adalah metode yang digunakan dalam penelitian ini. Digunakannya metode ini adalah untuk memeroleh data-data deskripsi yaitu deskripsi variasi dan faktor-faktor apa saja yang menjadi penghambat dalam pembelajaran Bahasa Indonesia Mahasiswa Universitas Bina 
Darma di masa pandemi. Ada pun kevariasian itu dapat dibedakan menjadi dua yaitu variasi dari segi mengajar dosen dan variasi dalam pemberian tugas kepada mahasiswa.

Wawancara dan observasi adalah teknik pengumpulan data yang dilakukan kepada para dosen mata kuliah Bahasa Indonesia dan beberapa mahasiswa Universitas Bina Darma semester ganjil tahun akademik 2020/2021. Selain itu dilakukan pula pengamatan terhadap aktivitas yang dilakukan oleh dosen ataupun mahasiswa disaat pembelajaran berlangsung. Dalam menganalisis data yang diperoleh, penulis menggunakan model interaktif yang melalui tiga tahap yaitu reduksi data, sajian data, dan penarikan simpulan, (Gunawan, 2014). Reduksi data dilakukan dengan cara mengelompokkan datadata yang termasuk pada variasi mengajar dosen, variasi pemberian tugas, serta faktor-faktor penghambat dalam pembelajaran Bahasa Indonesia mahasiswa Universitas Bina Darma di masa pandemi. Penyajian data dalam penelitian ini mendeskripsikan temuan tentang berbagai variasi megajar dosen, variasi pemberian tugas kepada mahasiswa, serta menyajikan faktor-faktor penghambat dalam pembelajaran Bahasa Indonesia mahasiswa Universitas Bina Darma di masa pandemi. Jelasnya bahwa, semua kegiatan dalam pengumpulan dan analisis data dilakukan berdasarkan pada teori-teori yang menjadi pedomannya. Setelah semua tahap pada pengumpulan dan analisis data dilakukan, maka dilakukan proses penarikan simpulan.

\section{HASIL DAN PEMBAHASAN}

\subsection{Variasi dalam Pembelajaran Bahasa Indonesia Mahasiswa Universitas Bina Darma di Masa Pandemi}

Variasi dalam pembelajaran Bahasa Indonesia Mahasiswa Universitas Bina Darma di masa pandemi dapat dilihat dari kegiatan pembelajaran seperti variasi mengajar dosen dan variasi pemberian tugas.

\subsubsection{Variasi Mengajar Dosen}

Kegiatan pembelajaran Bahasa Indonesia mahasiswa Universitas Bina Darma di masa pandemi dilakukan dengan cara "Pembelajaran Jarak Jauh (PJJ) atau yang sering disebut dengan "daring” (dalam jaringan). Hal ini dikarenakan untuk mencegah meluasnya penularan virus korona, dan tentunya berbeda dengan aktivitas pembelajaran di masa normal seperti biasanya yang dilaksanakan di kelaskelas dan secara langsung dilakukan kegiatan tatap muka. Senada dengan hal di atas Bilfaqih dan Qomarudin (2015) juga mendefinisikan bahwa "pembelajaran daring sebagai program penyelenggaraan kelas pembelajaran dalam jaringan untuk menjangkau kelompok target yang masif dan luas".

Metode pembelajaran daring, sebenarnya sudah lama diterapkan di Universitas Bina Darma jauh sebelum adanya pandemi corona yaitu melalui sistem E-Learning. Pembelajaran sebelum 


\section{JURNAL ILMIAH \\ BINA EDUKASI \\ ISSN 1979-8598 E-ISSN: 2655-8378 \\ http://journal.binadarma.ac.id/index.php/jurnalbinaedukasi \\ Vol. 13, No. 2, Desember 2020, 66 - 75}

adanya pandemi corona atau di masa normal dilakukan dengan sistem: tatap muka di kelas sebanyak sembilan (9) kali pertemuan dan penggunaan E-Learning sebanyak tujuh (7) kali pertemuan, sehingga total pertemuan pada pembelajaran sebanyak enam belas (16) kali pertemuan. Sedangkan, pembelajaran yang dilakukan di masa pandemi dilakukan secara full daring baik E-Learning maupun bentuk pembelajaran lainnya yang dilaksanakan secara daring dengan total pertemuan sama yaitu sebanyak enam belas (16) kali pertemuan.

Bahasa Indonesia adalah salah satu mata kuliah dasar umum (MKDU) dan termasuk pada kategori mata kuliah universitas di Universitas Bina Darma. Pembelajaran Bahasa Indonesia di Universitas Bina Darma diampu oleh dosen-dosen mata kuliah Bahasa Indonesia yang berjumlah tujuh (7) orang dosen, akan tetapi pada pembelajaran semester ganjil tahun akademik 2020/2021, mata kuliah Bahasa Indonesia hanya diampu oleh lima (5) orang dosen saja, hal ini dikarenakan dua (2) orang dosen yang lainnya sedang melakukan tugas belajar.

Berdasarkan hasil wawancara yang dilakukan kepada para Dosen Mata Kuliah Bahasa Indonesia, diperoleh bahwa pembelajaran Bahasa Indonesia yang dilakukan oleh para Dosen Mata Kuliah Bahasa Indonesia kepada mahasiswa di Universitas Bina Darma sangat beragam, hal ini disesuaikan dengan keterampilan para dosen dalam memberi materi ajarnya terutama pada penguasaan IT (teknologi informasi), yang dapat dilihat pada tabel berikut ini.

Tabel 1. Variasi Mengajar Dosen

\begin{tabular}{lcl}
\hline No. & Nama Dosen & \multicolumn{1}{c}{ Media } \\
\hline 1. & $\mathrm{~A}$ & $\begin{array}{l}\text { E-Learning, Zoom, WhatsApp, E- } \\
\text { mail, Google Classroom, dan } \\
\text { YouTube. }\end{array}$ \\
\hline 2. & $\mathrm{~B}$ & \begin{tabular}{l} 
E-Learning, Zoom, dan WhatsApp \\
\hline 3.
\end{tabular} \\
\hline 4. & $\mathrm{C}$ & E-Learning, Zoom dan WhatsApp \\
\hline 5. & $\mathrm{D}$ & E-Learning dan Zoom \\
\hline
\end{tabular}

Dari tabel 1 di atas, diketahui bahwa variasi mengajar yang dilakukan oleh para Dosen Mata Kuliah Bahasa Indonesia sangat bervariasi, meski pun ada beberapa penggunaan media atau aplikasi yang sama.

E-Learning adalah salah satu fasilitas yang digunakan oleh Universitas Bina Darma sebagai sarana untuk menunjang kegiatan pembelajaran secara daring dan telah terhubung langsung dengan laman sitem pembelajaran dalam jaringan Indonesia "spada" milik Kemendikbud RI. Semua kegiatan permbelajaran dapat dilakukan oleh dosen di E-Learning, seperti membuat kontrak perkuliahan, mengunggah RPS, mengunggah materi perkuliahan, materi referensi dari ebooks atau laman website serta membuat forum diskusi, mengirim tugas termasuk kuis, UTS dan UAS. 


\section{JURNAL ILMIAH \\ BINA EDUKASI \\ ISSN 1979-8598 E-ISSN: 2655-8378 \\ http://journal.binadarma.ac.id/index.php/jurnalbinaedukasi \\ Vol. 13, No. 2, Desember 2020, 66 - 75}

Selain E-Learning, para dosen juga dapat memanfaatkan media Zoom yang telah difasilitasi juga oleh kampus melalui Zoom Pro yang dapat digunakan dengan batas waktu yang lama dan peserta yang cukup banyak dibandingkan dengan Zoom yang personal. Untuk penggunaannya sendiri, dosen dapat meminta akun (ID zoom) di bagian pengajaran. Zoom ini biasanya digunakan untuk tatap muka virtual menggantikan tatap muka langsung di kelas sebagaimana biasanya, dengan tujuan agar dosen dan mahasiswa dapat mengenal lebih dekat atau berinteraksi secara langsung.

WhatsApp (WA) adalah media yang paling cepat untuk merespon dan sering digunakan oleh dosen, bahkan para dosen dapat membuat "WAG" (WhatsApp Group) per kelas untuk membagikan informasi-informasi yang berkaitan dengan perkuliahan.

Selain E-Learning, dosen juga dapat memanfaatkan E-mail atau surat elektronik, Google Classroom dan YouTube sebagai sarana untuk mengirim matari perkuliahan dan tugas lainnya kepada mahasiswa. Namun, tidak banyak dosen yang menggunakannya terutama Google Classroom dan YouTube, hal ini dikarenakan kemampuan dosen yang berbeda-beda.

\subsubsection{Variasi Pemberian Tugas}

Variasi pemberian tugas yang dilakukan oleh para Dosen Mata Kuliah Bahasa Indonesia kepada mahasiswa Universitas Bina Darma, tidak jauh berbeda dengan variasi mengajar yang telah dijelaskan sebelumnya, terutama pada penguasaan keterampilan menggunakan IT. Selain penguasaan $I T$, hal lain yang terjadi pada saat pemberian tugas ini karena mahasiswa yang diajarkan adalah mahasiswa yang berasal dari program studi berbeda-beda. Pada semester ganjil tahun akademik 2020/2021 mahasiswa yang mengikuti mata kuliah Bahasa Indonesia terdiri dari mahasiswa program studi: sistem informasi, teknik informatika, psikologi, manajemen informatika, manajemen dan teknik industri.

Adapun pemberian tugas yang diberikan tersebut seperti pada: (1) materi pertemuan kedua yaitu fungsi dan ragam bahasa, Dosen A (membuat video pembelajaran tentang materi Bahasa Indonesia untuk diunggah ke E-Learning dan YouTube); Dosen B (praktik sebagai pembaca berita untuk ditampilkan di Zoom); Dosen C (mengerjakan tugas tentang ragam bahasa formal dan nonformal di E-Learning); Dosen D (meringkas materi pertemuan kedua dengan bahasa sendiri dan diunggah ke E-Learning); dan Dosen E (membuat makalah tentang fungsi dan ragam bahasa Indonesia dan dikirim ke E-mail), (2) materi pertemuan kelima tentang pemilihan kata atau diksi, Dosen A (menganalisis penggunaan diksi pada pidato di tokoh Youtube); Dosen B (mencari iklan di internet, kemudian mencari kata baku dan tidak baku); Dosen C (membuat kamus sederhana menggunakan kata baku sesuai dengan bidang ilmu masing-masing kemudian diunggah ke $E$ Learning); Dosen D (mengerjakan tugas di E-Learning tentang syarat-syarat ketepatan diksi); dan Dosen E ( menganalisis gaya bahasa yang dipakai pada percakapan di WAG). 
Berdasarkan uraian di atas jelas bahwa variasi pemberian tugas tidak jauh berbeda dangan variasi mengajar dosen. Dosen menggunakan metode daring melalui media E-Learning, Zoom, Youtube, WhatsApp, dan E-mail.

\subsection{Faktor Penghambat Pembelajaran Bahasa Indonesia Mahasiswa Universitas Bina Darma di Masa Pandemi}

Faktor-faktor yang menjadi penghambat pada variasi pembelajaran Bahasa Indonesia berdasarkan sumber dari para dosen yaitu berupa faktor internal dan faktor eksternal. Adapun yang menjadi faktor internal yaitu berupa kata-kata yang menggambarkan perasaan dosen dan mahasiswa seperti stres, bingung, galau, khawatir, sabar, senang, menantang, sedih, semangat, cemas, malu, motivasi, inovasi, kreatif, luar biasa, tanggung jawab, dan risiko. Faktor-faktor internal yang dimaksud di sini yaitu berupa: (1) adanya kesiapan yang dilakukan oleh dosen sebelum mengajar seperti RPS, materi yang disajikan dalam bentuk power point yang dapat dilengkapai dengan audio visual, $p d f$, konten Youtube serta tautan referensi dari website: (2) membuat soal forum atau tugas, memberikan respon atau tanggapan dan penilaian dari setiap forum dan tugas yang telah diunggah oleh mahasiswa: serta (3) membuat jadwal pertemuan virtual kepada mahasiswa dan melaporkan dokumentasi pertemuan virtual ke E-Learning.

Sedangkan faktor eksternal yaitu berupa kuota internet, sinyal atau jaringan internet, wifi, sarana dan prasarana, respon, dan teknologi. Senada dengan penelitian yang dilakukan oleh Ernawati (2020) bahwa "jaringan internet, kuota internet, dan "wifi" adalah penunjang utama yang digunakan untuk mengakses e-learning, sur-el, dan whatsapp". "Semakin besar dokumen atau media pembelajaran yang digunakan maka semakin membutuhkan kuota internet yang banyak".

\section{SIMPULAN}

Berdasarkan hasil penelitian dan pembahasan sebelumnya maka dapat disimpulkan bahwa:

(1) Variasi mengajar dosen sangat beragam yang disesuaikan dengan penguasaan dan keterampilan para dosen dalam menggunakan IT untuk berinteraksi dengan mahasiswa seperti penggunaan konten E-Learning, E-Mail, Zoom Meeting, Google Classroom, WhatsApp, dan Youtube;

(2) Variasi dalam pemberian tugas juga sangat beragam, disesuaikan dengan kemampuan dosen dalam memnggunakan IT dan untuk pelaksanaannya masih sama seperti pada variasi mengajar dosen yaitu dengan memanfaatkan sarana dan prasarana yang ada dan bisa;

(3) Faktor penghambat pelaksanaan variasi pembelajaran Bahasa Indoesia mahasiswa Universitas Bina Darma meliputi faktor internal dan faktor eksternal. 


\section{DAFTAR PUSTAKA}

Alma. (2009). Guru Profesional. Bandung: Alfabeta.

Barokah, Muh Ali, Laili Etika Rahmawati, Markhamah. (2020). Variasi Tugas dan Aktivitas Pembelajaran dalam Masa Pandemi Korona di SMK. PEMBELAJAR: Jurnal Ilmu Pendidikan, Keguruan, dan Pembelajaran Volume 4 Nomor 2 Oktober 2020. https://doi.org/10.26858/pembelajar.v4i2.14118. Diunduh 12 November 2020 .

Bilfaqih, Yusuf, dan M. Nur Qomarudin. (2015). Esensi Pengembangan Pembelajaran Daring. Yogyakarta: Deepublish Publisher.

Diunduh 12 Desember 2020.

Ernawati, Yeni. (2020). Problematik Pembelajaran Daring Mata Kuliah Bahasa Indonesia. Jurnal Ilmiah Bina Edukasi, Volume 13, Nomor 1, Edisi Desember 2020, hlm.01-15.

http://journal.binadarma.ac.id/index.php/jurnalbinaedukasi/article/view/1029/573.

Gunawan, Imam. (2014). Metode Penelitian Kualitatif: Teori dan Praktik. Jakarta: Bumi Aksara.

Kemendikbud RI. (2020). 7 Tips Mengajar dari Mas Menteri [Hardiknas 2020]. https://www.youtube.com/watch? $v=G S 7 k 6 e R 1 Q I s \& t=25 s$. Diunduh 10 September 2020.

Majid, Abdul. (2013). Strategi Pembelajaran. Bandung: PT Remaja Rosdakarya.

Mulyasa. (2013). Pengembangan dan Implementasi Kurikulum 2013. Bandung: PT Remaja Rosdakarya.

Paraningsih I.G.A.S, Sudiana I.N., Putrayasa I.B. (2016). Variasi Mengajar Guru Bahasa Indonesia di Kelas VIII SMP N 2 Sawaan. E-Journal Pendidikan Bahasa dan Sastra Indonesia Universitas Pendidikan Ganesha. Jurusan Pendidikan Bahasa dan Sastra

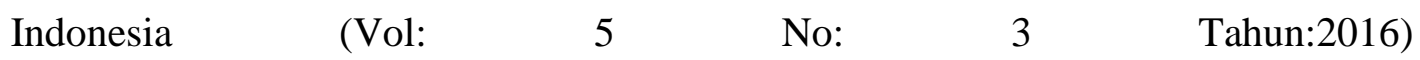
https://ejournal.undiksha.ac.id/index.php/JJPBS/article/view/8691. Diunduh 15 Oktober 2020.

Sevima. (2020). 6 Metode Pembelajaran Paling Efektif di Masa Pandemi Menurut Para Pakar. https://sevima.com/6-metode-pembelajaran-paling-efektif-di-masa-pandemimenurut-para-pakar/. Diunduh 10 September 2020. 